course no onc faught the donkey to do this: but the quadruped gave the biped a practical. Iesson, from which I am not aware that they drew the abstract verbally formulated conclusion that reason may he exercised without rhetoric.

Mircli it

IIENRY MUIKHEAD

I BELLEVE that unstances of rats gnawing throurh water-pipes are frequent. Two have coune to my knowledge during the past fortuight. The one instance occurred at the house of a gentle. man near West Hartlepool ; in the other case a large hole, $3 \frac{1}{4}$ inches long, and varying from 13 ths of an inch to $1 \frac{1}{8}$ th inch in breadth, was gnawed in the fresh-water pipe of the screw. steainer Mary Coveriale. A portion of this pipe, containing the hole, was cut off, and is preserved by me; it is a stout leaden.pipc, a quarter of an inch thick, and with a diameter of $2 \frac{3}{8}$ inches. It is very doubtful whether there was any flaw before the hole was begun.

West Hartlepool

\section{Distribution of the Black Rat}

PERHAIS some of the readers of NATURE may be able to throw some light on the present geographical range of the Black Rat (Mus rattus, L.). In the early jart of 1877 some individuals of this species came on board the steanship Lady Fronces either at Bombay or at Rangoon, but, as the captain believes, at the latter port. The animals inultiplied on board the vessel, and in August last I had the pleasure of receiving from the ship a living specimen, which was at once forwarder to the Zoological Cardens in Regrent's Park, where, I believe, it may still be seen. In a "Catalorue of the Mammals of the Sabara," by my friend, Camon Tristran, F.R.S. (wide "The (ireat Sabara," P. $3^{8} 5$ ), the author states that the "Far el Klia," as the black rat is called by the Arriss, "still maintains its position" in the Alocrian Safiara. And I was yesterday presented by Mr. F. lonald Thompon, of Seaton-Carew, with a skin of Mus ruthus from New Zealand. This example, like those from Bumual, was brought over by a vessel (the 7rody $a n$ ) which loaded grain at l.yitelton, in the provinec of Canterbury, New $/$ caland, where the rats embarked. In August, 1878, I)r. Sclater, F.R.S., was good enough to inform me that "M/us ro!tus has rather an extensive zange over Furope and Western Asia," and adided, "I fear it would not be possible to state it very exactly." But it is evident that the range of the species is mucle wider, as it is known to occur in Nonth Africa, British India, and New \%ealand ; and it is also said, by Prof. Fell ant Mr. Macgillivray, to have been carried to America and the South Sea lislinds by ships. I should be glad to have further cvidence as to its occurrence in Burbah, and it woild be also desirable to know if it is found in the Malay Archijelagis, China, Japan, or Austialia. Dr. Peters, of the Zoological Museum at Berlin, assured me, in June last, that the species was cxtremely rare, if not actually extinct, in Gernany, and showed me the only specimen in the fine collection under lris care-an old and faded skin from Hanver. The animal lingers in one old building at Stockton-on-Ices, and there is ciearly a possibility of its being reintroduced in many seaport fowns through the agency of ships.

West Harliepoul, March i I R. MorTon Midularox

\section{The United States Fisheries}

IN your review of the report of the $U_{\text {nited }}$ States Commission of Fish and Fisheries, you say you are of opinion there is almost wo difference between Salno salar and Sizlmo quinnat. My friend Prof. Baird sent me bis report some time since, and also forwarded several thousand eggs of Sa!mo quinna! for experi. nicui in the liatching tanlis of the Southport Aquarium. 'The eggs hatched out remarkably well, a very small percentage only being lost, and have proved much more hardy and tenacious of iife than any. Salmo salar I ever had to do with, and very ruuch easier to feed. Salmo salar have never done well except when fed on the minute red worms found on the mud in the beds of sonue rivers and streams (our supply was obtaned from the Thames). Salme quininat, however, liye well, and grow faster on the roe of fish (refuse from the fish market), such as whiting, than $S$ salay will on anything. From what I have seen of them I quite agree with Prof. Baird in his admiration of this member of the salmon family, and I share his surprise that it has attracted $s$, little attention amone Finglish fish-cillurists. It

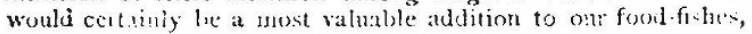

stronger, and apparentiy of more rapid growth than our native siecies. On the contincnt, and in New Zealand and other countries, it is most greedily sought after, and each season for several years past an agent has carried from America to France, Germany, and other countries, large consignments of the ova. In England, so far, it appears to have been quite neglected. Hill Fold, Bolton, March 15 CHAS. L. JACKSON

\section{Plovers in the Sandwich Islands}

I CAN vouch for the truth of the visit of golden plovers to the Sandwich Islands mentioned by Prof. A. Newton in NaTURE, vol, xix. p. 433. They are very numerous during the winter from November until Marcl. I do not know the scientific name, but I have shot a great many on Oahu and. Hawaii.

If it will help Mr. Newton in the solution of the very interesting question he raises I may mention that M. Bailliere, ConsulGeneral for France at Ionolulu, is in the babit of sending specimens of birds to (I think) the Jardin des Plantes, Paris, wihere doubtless a specimen might be found. Iertford, March I5

\section{Unscientific Art}

IN the Grafilic for December 28 there appeared a sketch of a unan taking a reading on a marine barometer, on board the Sarmation, during the voyage of the Marquis of Lorne to Canada. To see the scale better by the light of his lantern, the observer is represented as sloping the barometer at an angle of about $30^{\circ}$ from the vertical.

New Kingswood, Bath JOIN W. BUCK

\section{ON THE POSSIBILITY OF EXPLAINING TIIE CONTINUANCE OF LIFE IN THE UNIVERSE CONSTSTENT WITH THE TENDENCY TO} TEMPERATUKI-ELUILIBNILM

THE idea of the ultimate final cessation of all physical change and life in the universe ${ }^{1}$ has been contemplated by many physicists with some dissatisfaction, and with the desire if possible to find some explanation or physical means by which so apparently purposeless an end is averted, and of avoiding the necessity for assuming in past time a violation of physical principles at present recognised to exist. ${ }^{2}$ Several attempts have been made to surmount the difficulty, ${ }^{3}$ but apparently with no generally satisfactory result. Having given much time to physical problems having a relation more or less to this question, and haring always kept the question itself in view, I should like to submit the following conclusion to the readers of NATURE as an attempt to solve the difficulty, though what I have to bring forward is probably not entirely new, as considerations partially tending towards. the same final result bave already been published by Mr. James Croll, Phil. Mag., May, 1868," On Geological Time;" and Mr. Johnstone Stoney, "On the I'hysical Constitution of the Sun and Stars," Proc. of the Royal Society, 1868-69. The groundwork of what I have to suggest may be described in a few words. ${ }^{5}$

Taking a general view, of the universe, we mayconsider it as so much matter, which contains a certain quantity of energy. Let us suppose for illustration the encrgy of "Thoinson, "On the Universal Tendency in Nature to the Jissipation of Pog An". Science," second edition, p. 22 .

2 The allied idea of the whole universe tending to agglomerate into onc mass under the action of gravity, the notion of insiability thus involved, all mass under the action of gravity, the notion of insiability thus involved, all scarcely in harmony with the orderly working of physical phenomena, and scarcely in harmony with tize orderly work:ng of physical phenomena,
would secin to point to the necessity for some additional explanation.

w Grove, "Corr. of Physical Forces," p. 67: Rankine, "On the Reconcen-
3 Grover 3 Grove, "Corr. of Physical Forces," P. 67: Rankine, "On the Reconcen-
tration of the Mechanical Energy of tite Eniverse," Phil. Mug., Novenber, $\mathrm{i}_{52}$, Sc., \& \&

852 , Sic., Sce.
4 Alsi) Quarterly Yourut of Science, July, 1877 .

4 Alsis Quarterly Fourut of Science, July, 1877 .
5 The same problem was considered by the writer in special reference to I.e Sage's theory of gravitation in the pharterly foumal of Science for July last, bet my present object is to deal with the question entircly independently last, bit my present object is to deal with the question entircly independently
of any squecial theories, and solely on the hasis of ge:erally accepted facts, of any squecial theories, and solely on the hasis of ge:terally accepted facts,
or facts which if $2 x$ known vould be :a latm nny with or deducible fromi tian: which ate known. 